\title{
Chapter 9 \\ The Entangled Infrastructures \\ of International Student Migration: \\ Lessons from Covid-19
}

\author{
Parvati Raghuram and Gunjan Sondhi
}

\subsection{Introduction}

International students are a growing share of the global migrant population. The top two countries of origin are China and India while the top destinations are the United States, Australia, and the United Kingdom (Fig. 9.1). Students are often considered to be transient and therefore not pertinent to the politically divisive dialogues around migration in many countries. Perhaps, as a result, through the second half of the twentieth century, when migration moved up on research agendas, student migration research was still relatively embryonic. However, there has been an explosion of research in the last two decades tracing the causes, experiences, and consequences of student migration as student migrant numbers have increased (Brooks \& Waters, 2011). They have produced new insights and agendas for research (King \& Raghuram, 2013).

If international student experiences have been based on the lack of permanence, i.e., the itinerancy of study, then it is precisely this lack of permanency that has made international students some of those hardest hit by Covid-19 (Bilecen, 2020) as it exposed the liminalities that are inherent to study but also the constitutive nature of mobility ${ }^{1}$ to higher education today.

\footnotetext{
${ }^{1}$ In this chapter we use the terms migration and im/mobility in specific ways. International student migration is the lens through which this chapter examines the infrastructures of migration- corporeal, knowledge, and finance. A deeper discussion of the nuances of migration and mobility is beyond the scope of this chapter.
}

\footnotetext{
P. Raghuram

Geography, The Open University, London, UK

G. Sondhi $(\bowtie)$

Geography, The Open University, London, UK

e-mail: gunjan.sondhi@open.ac.uk
} 


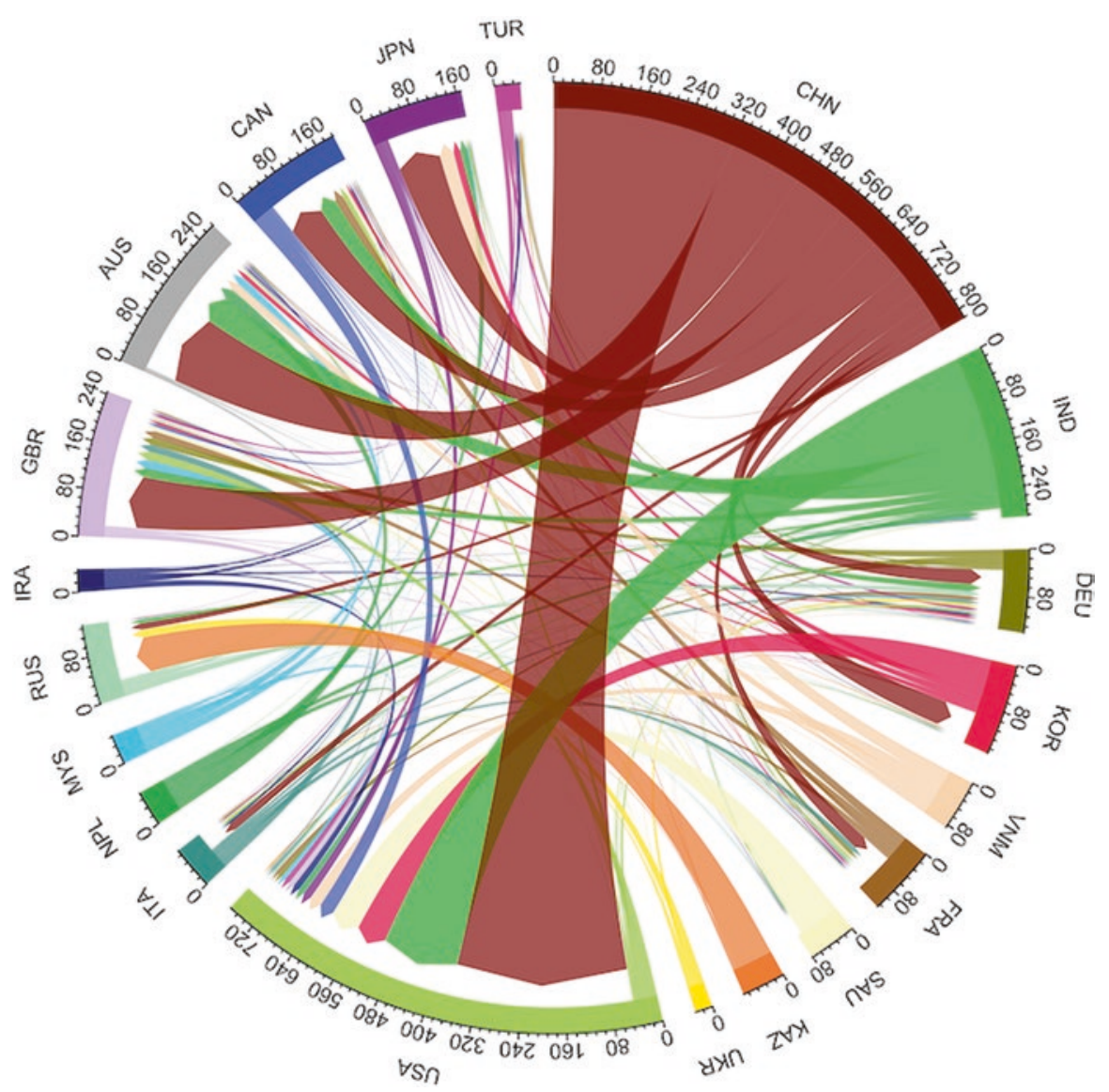

Fig. 9.1 Global flows of international students in 2017 (top 20 countries). (Source: OECD)

This chapter focuses on the experiences of international students in the UK during the Covid-19 pandemic in 2020. It particularly addresses the altered mobilities and immobilities produced by the pandemic and the infrastructures that shaped them. The rest of the chapter is divided into four further sections. The next section outlines how Covid-19 may be seen not only as a crisis, but also as a conjuncture that exposes the infrastructures shaping student lives. It suggests that focusing on the fissures in the infrastructures that are supposed to support the mobility of international students offers a useful lens for migration research. Section three outlines the project and data collection methods and describes the international students who participated in the study. The fourth section delves into the experiences of international students to show how the entangled infrastructures of education, migration, and finance failed during the pandemic, leading to particular forms of immobility and mobility for international students. The section argues for deeper examination of these infrastructures to capture the inherent liminality of the lives of international 
students. The chapter concludes by exploring the implications of these findings for theoretical and policy research.

\subsection{Covid-19 and Infrastructures of International Student Migration}

The Covid-19 pandemic led to the introduction of short-term but stringent measures to control the spread of the virus. When the outbreak was first detected, it was difficult to comprehend and anticipate the intensity, nature, and length of disruption to our normal lives. For students in destination countries, the hope was that the interruption to study would be short term, but the challenges faced by international students revealed the fractures in the infrastructures shaping student lives. Conceptualising Covid-19 as a crisis provides us a productive entry point towards exploring the failures in these infrastructures and how international students negotiate them.

Covid-19 as crisis, like other crises, offers opportunities for unpacking what went before. Crises then are not events, but condensed moments where the internal contradictions of a period come to light (Hall \& Massey, 2010). They highlight the complex entanglements of the social and cultural character not only of the crisis but also the conditions under which it arose.

Infrastructures offer one way of exploring that character. Migration and mobility scholars have, for some time, focused on the infrastructures of mobility (Hannam et al., 2006) and immobility (Breines et al., 2019). Xiang and Lindquist define 'migration infrastructures' as 'the systematically interlinked technologies, institutions, and actors that facilitate and condition mobility' (2014, S124). International migration and its infrastructures, which link 'technologies, institutions, and actors' have been analysed for how they enable different forms of mobility. For instance, authors have explored the role that intermediaries such as education brokers, employment agencies, and migration brokers play in facilitating student and skilled migration (Cranston, 2017; Harvey et al., 2018). Student migrants are filtered and stopped through a range of methods from fee requirements to visas. Their onward mobility and their presence are also governed and securitised through everyday bordering (Dear, 2018).

The intertwining of infrastructures of mobility and immobility, and how they shape international students' mobility is highly differentiated by nationality and class. For instance, students from some countries, particularly in Africa, have fewer venues to go to get their visas to study in the UK as visa functions are centralised in major sending countries. Moreover, the infrastructures around funding are variable based on whether students travel on scholarships or through personal funding or loans. Finally, some apparatuses and technologies, institutions, and intermediaries appear far more significant when viewed through the eyes of such migrants than they appear in the eyes of the receiving countries. 
These infrastructures of mobility were particularly affected during the Covid-19 crisis. Mobility is central to this pandemic. Viruses travel on moving objects and bodies so the only solution to this crisis is to make them immobile. It requires stasis to contain the virus. People stopped wherever they were, irrespective of status and location. In some senses, the story of the solution to the spread of Covid-19 is immobility. This had social effects - with people only allowed to mix socially in bubbles with tightly drawn boundaries and encouraged to work from home if they could as well as with compulsory regulations stopping movement except for defined purposes. Educational institutions were also initially closed for face-to-face study but over time the restrictions were partly lifted.

However, Covid-19 did, in effect, lead to large scale mobility (Rajan, 2020). The pandemic triggered an economic downturn, with extant job losses and global recession which fed right through the economic system. People who lost jobs went back - to their home countries as well as to their rural homes. Both the informal economy and the lowest-paid sectors such as hospitality, which employs large numbers of migrants in cities, contracted sharply. The rural economy - and sending countries, themselves affected by the pandemic - however, had to accept large numbers of return migrants.

Mobility and immobility were thus entangled in the strategies for containment of Covid-19. International students were amongst the first to feel the impact of the Covid-19 crisis. Chinese students, the largest cohort of international students globally, returning from the festive break at the turn of the year, were subject to quarantining mingled with an unhealthy dose of racism. Those who returned found that they had little ability to then return to their home countries as borders hardened and travel restrictions grew. Those who were wealthy and healthy could return. However, not all international students are wealthy and able to buy airline tickets at short notice and at inflated prices. They stayed. Many students were unable to 'go home' as the other infrastructures that are supposed to support and enable mobility were also failing, consequently immobilising students both within their country of destination and within the sending countries.

Despite these issues, the first and most persistent concerns about international students were not around their welfare but on what a system of education based on mobility would do without international students (Gamlen, 2020). Universities UK (UUK) estimates that the education sector generates $£ 13.1$ billion in export earnings. This helps underpin employment of around 940,000 people across the sector. It, therefore, requested 'a balanced package of measures to maximise universities' contribution to the economy, communities and the post virus recovery,' i.e., a cash injection of about $£ 2.2$ billion to help the sector cope with the outcomes of the Covid-19 pandemic (Universities UK 2020). Universities UK argued that the potential loss in revenue could be over $£ 790$ million in $2019-2020$ and potentially $£ 6.9$ billion in 2020-2021 if there was a drop in international students' enrolments as these were critical to the financial health of the sector (Ahlburg, 2020). Similarly, the Australian government abandoned students until the impact of this attitude on future student flows was driven home (Nguyen \& Balakrishnan, 2020). The infrastructural role that international student fees play in constituting educational 
institutions and systems is little recognised and analysed but became particularly apparent during the pandemic. It led to new registers of recognition of the role that international students play in higher education.

However, the issues faced by students received much less attention. There were some media reports, but they remained marginal to mainstream concerns about the effect of Covid-19 on UK higher education. Our project aimed to address this lacuna through a small-scale study of the issues that the students themselves faced. The next section outlines the study and the methods adopted.

\subsection{Studying International Student Migrants During Covid-19: Digital Methods}

The research presented in this chapter is based on a project that emerged out of concerns for international students during the initial stages of the lockdown in the UK (Raghuram \& Sondhi, 2020). It aimed to capture the experiences of the pandemic on the 2019-2020 cohort of international students in the UK. The study used online methods, which were widely adopted by research communities studying migration during the pandemic. The researchers knew before embarking on the study that while the subject of their study was clear, the field site of their study was less clear, and required further consideration. The researchers were also sensitive to the ethical issues and safety concerns of both the researchers and participants.

This research took shape amidst the pandemic as well as the Black Lives Matter movement and the calls to decolonise the curriculum and research that accompanied it. The research was undertaken after obtaining ethical clearance from the university. Although some meetings were allowed by the time the research was undertaken, ethics clearance was only requested and obtained for online interviewing. The researchers had considerable experience of undertaking online interviews in previous research. By undertaking the data collection entirely online, the research challenged our assumptions of the 'field', but also forced us to think of what the field meant at a time when the media was full of stories, such as those around the illness itself, and to the mobility limitations being imposed, that were directly relevant to the students. The field, in this research, therefore included the contexts within which research problems were conceptualised and designed. We were conscious that these problems were pressing for many students but that the students were also vulnerable in the context of very rapidly changing regulations.

There are four ways in which the digital appears in research. Drawing on scholarship on the 'digital turn' in geography the digital in this paper was understood as:

(a) an interface through which access to the field is mediated

(b) a field site where data can be generated

(c) field of concern about how data is generated

(d) offering opportunities for generating various sorts of 'telling' geographies as outputs. 
In our project we primarily used the digital as interface. We used a mainstream meeting software offered through our university and in doing so were able to access students, irrespective of physical location. This included students who had physical disability. However, we were aware that other forms of exclusion were operating. For instance, those with limited bandwidth or inability use the software or unwilling to download the software. Those who were concerned about digital interviewing too would, no doubt, have opted out although the ease with which participants interact online had no doubt been strengthened by the time we undertook the interviews. Students had been exposed to hours of online learning after universities closed faceto-face teaching in March 2020, as such, the digital also became our field of/for concern as we considered the inclusions and exclusions digital methods pose. The digital was not then simply an interface.

The study employed a mixed-method approach to data collection using a bespoke online survey on a software platform and in-depth online interviews. The survey ran from August 2020 to 15 October 2020. The project was advertised through the researchers' Twitter accounts, and their respective Twitter networks, as well as other channels offered by the project partner UK Council for International Student Affairs (UKCISA). UKCISA circulated the call for participation through their social media platforms and their student ambassadors. Interview respondents were recruited from among the survey respondents; survey respondents who expressed an interest in being interviewed were contacted by researchers.

The survey generated a total of 85 complete responses. Sixty per cent of respondents identified as women. Of the remaining $40 \%$, the majority identified as men, and a smaller group identified as non-binary. ${ }^{2}$ International students were defined as those who were enrolled in UK higher education institutions as international students either on a Tier 4 visa $^{3}$ or paying international student fees or both. Unlike other studies, two definitions were used to identify international students. This was to capture students with dual nationalities who may not need a visa to be in the UK because they hold EU or British passports, but do not meet the residency criteria that makes them eligible for home fees. ${ }^{4}$ This project, therefore, includes British-born migrants who may be returning to the UK for higher education. The data collected through the individual survey aimed to be illustrative rather than representative. The survey captured a cross-section of students who were studying in the UK from around the world. This is in contrast to other recent studies that have focused on

\footnotetext{
${ }^{2}$ Specific percentages are not provided because of data privacy issues.

${ }^{3}$ Tier 4 (General) Student is the visa category a person needs to have in hand if entering the UK for study. From October 2020, 'Student Visa' replaced the Tier 4 (General) category. This was because the UK moved to a Points Based migration system.

${ }^{4}$ To avail of UK home-based fees, students need to demonstrate residency in the UK up to 3 years prior to starting study, i.e., continued stay at a UK residence. Prior to 2021, for EU citizens to be eligible for home status fees, they had to show evidence of three-year prior residency at an EU address. The implications of this eligibility requirement are that British or EU nationals (holding British or EU passports) are not automatically eligible for home status fees if they cannot prove residency for 3 years prior. Hence, there are several cases where British and EU passport holders also pay international students rate fees.
} 
specific sending countries such as Chinese students abroad (Hu et al., 2020) and Indians in Germany (Jayadeva, 2020). The survey was organised around seven broad themes to explore the impact of the crisis on students: experiences of migration, education, financing, housing, social exclusion/racism, institutional support, and future intentions.

The majority of respondents were under the age of 33 years $(75 \%)$ and many were enrolled in a Masters-level program of study (42\%). Nearly $60 \%$ of the respondents were single, with another $37 \%$ either in a relationship or married. Thirty per cent of the respondents selected China as their primary nationality. This was double the number of the next most populous group, Indian nationals (15\%). The survey also captured the experiences of students from West African countries (Nigeria, Ghana), North America (US, Canada), Latin American countries (Brazil and Columbia), and South-East Asian countries (Malaysia and Singapore) (Table 9.1).

In addition to the survey, the project also included ten in-depth interviews with students to contextualise and explain the data. The interviews were conducted in September and October 2020, as the UK was emerging out of lockdown and international student recruitment was picking up. Universities UK was reflecting on the absence of the drop in international student figures, and this formed the background to public discussions at this time. Each interview lasted an average of $45 \mathrm{~min}$. Of the ten students interviewed, eight were based in the UK at the time of the interviews, one had returned to their home country as they had run out of funds and could not afford to live in the UK, and one respondent had started their studies at a distance in the midst of the lockdown, and hence had yet to enter the UK. The sample of interview respondents was gender balanced and included nationals from Asian and North American countries. The interviews followed the survey and explored the seven key themes in greater depth, the findings from which we will turn to below.

Throughout the research process we were conscious of the implications of this study for our participants. Briggs (1986) refers to interviews as 'speech' events and Johnson et al. (2004) as 'meetings'. Both these terms aim to draw attention to the relational and dialogic elements that are central to interviewing. They highlight the specific contexts and spaces that are created through the interactions. The context of the study was shaped by the difficulties that students had been experiencing which had been very upsetting and unsettling. During some interviews, students could barely hold back their tears as they talked about their family members and how much they missed them. Others spoke of resilience and holding on as pragmatic

Table 9.1 Top 5 nationalities by gender

\begin{tabular}{l|l|l|l}
\hline & $\mathrm{M}(\%)$ & $\mathrm{F}(\%)$ & Total \\
\hline China & 33 & 66 & 100 \\
\hline India & 66 & 33 & 100 \\
\hline Nigeria & 33 & 66 & 100 \\
\hline USA & 50 & 50 & 100 \\
\hline Malaysia & 40 & 60 & 100 \\
\hline
\end{tabular}

Source: Authors' COVID ISM Survey 
responses to uncontrollable events and uncertain futures. The interviewee was continuously conscious of these issues, sensing discomfort, and doing care work through and in the interviews. Care was particularly taken to ensure that participants were not left more grieved and in poorer shape than before. Both the authors had themselves been international students, albeit some time ago, giving them some insights into the issues that students face in the UK. They both have worked on international student migration for some years and have also supervised and mentored international students. They have argued for international students to be included in the global compact for migration as the fees that students pay is a form of negative remittance for sending countries (Raghuram \& Sondhi, 2017). They have written widely about the issues that students from the global south face (Raghuram et al., 2020; Sondhi, 2013, 2019). They thus came to this research with strong sensibilities around the issues facing student migration. Moreover, they have engaged in broader debates around the Indian diaspora in the UK and Canada and thus were sensitive to some of the racialisation that students were facing in the context of COVID-19 (Kim \& Sondhi, 2015, 2018). Thus, these 'meetings' involved shared experiences as well as differences.

\subsection{Migration Infrastructures and Failure}

International higher education was one of the first major global sectors to be significantly impacted by the Covid-19 pandemic because of the closure of borders and radical reductions in air transportation. It led to a range of hardships for students, several of which are discussed below. Moreover, it also showed the constitutive role that international students play in global higher education (Raghuram, 2013).

As lockdowns were announced, many of the students who could return to their home countries did so, but this was not always an option. Some students stayed on in their country of study because their courses involved laboratory work and copresence with supervisors - technological infrastructures and sites that were emplaced in their institution of study. Their studies could not all be moved online. As the policies being adopted by the universities were unclear, the students had to anticipate how the closure might affect their subject areas and decide if, for them, mobility was risky. Despite this some students left as uncertainties loomed large and families extricated their children. Others stayed on because of the time-lag between the closure of borders between the countries where they study and those to which they wanted to return but were now enforcing restrictions or simply did not offer enough means of transport to get back. Still others simply could not afford to go back and forth without some certainty of their future. These disabled, delayed, and disrupted mobility outcomes were the results of failures of migration infrastructures. Table 9.2 explores how these components differently interacted to produce differential mobilities and immobilities.

International students who were already in the UK as lockdowns began to be implemented in various parts of the world were faced with two options: they could 
Table 9.2 Components of infrastructures of migration that shaped mobility and immobility during the pandemic

\begin{tabular}{|c|c|c|c|}
\hline $\begin{array}{l}\text { Components of } \\
\text { Infrastructures }\end{array}$ & Unable to leave & $\begin{array}{l}\text { Unable to re-enter the } \\
\text { UK }\end{array}$ & $\begin{array}{l}\text { Unable to enter the } \\
\text { UK }\end{array}$ \\
\hline $\begin{array}{l}\text { Migration } \\
\text { policies }\end{array}$ & $\begin{array}{l}\text { Uncertain of whether they } \\
\text { would meet the Tier } 4 \\
\text { requirements in the UK } \\
\text { Uncertain of whether } \\
\text { post-study visa would } \\
\text { require a minimum period of } \\
\text { stay and students did not } \\
\text { want to jeopardise that } \\
\text { Unable to return to families } \\
\text { who were not living in the } \\
\text { country of citizenship }\end{array}$ & & $\begin{array}{l}\text { Uncertain of how } \\
\text { migration policy } \\
\text { might change due } \\
\text { to the pandemic }\end{array}$ \\
\hline $\begin{array}{l}\text { Consular } \\
\text { services }\end{array}$ & $\begin{array}{l}\text { Closure of offices due to } \\
\text { lockdown (unable to renew } \\
\text { passports for home country } \\
\text { where they had lapsed) } \\
\text { Delays in processing } \\
\text { biometric residence permits } \\
\text { for those who had arrived } \\
\text { recently }\end{array}$ & $\begin{array}{l}\text { Closure of offices due to } \\
\text { lockdown (unable to } \\
\text { renew visa applications) }\end{array}$ & $\begin{array}{l}\text { Slow processing } \\
\text { times }\end{array}$ \\
\hline $\begin{array}{l}\text { Higher } \\
\text { Education } \\
\text { Institutions }\end{array}$ & $\begin{array}{l}\text { Uncertain about whether } \\
\text { face-to-face studies were } \\
\text { suspended and for how long }\end{array}$ & $\begin{array}{l}\text { Uncertain about when } \\
\text { face-to-face studies will } \\
\text { be resumed }\end{array}$ & $\begin{array}{l}\text { Uncertain of } \\
\text { whether courses } \\
\text { would be offered } \\
\text { face-to-face or } \\
\text { online } \\
\text { Uncertain of the } \\
\text { value of online } \\
\text { study }\end{array}$ \\
\hline Financial & $\begin{array}{l}\text { Prohibitive cost of airfares } \\
\text { and uncertainty about when } \\
\text { flights might be cancelled } \\
\text { Prohibitive cost of living in } \\
\text { the UK without being able to } \\
\text { supplement with part-time } \\
\text { work }\end{array}$ & $\begin{array}{l}\text { Prohibitive cost of } \\
\text { flights. } \\
\text { Cancellation of flights } \\
\text { from sending country. }\end{array}$ & \\
\hline Travel & $\begin{array}{l}\text { Lockdown in receiving } \\
\text { country meant that students } \\
\text { could not fly back. } \\
\text { Flights were often cancelled } \\
\text { or reserved for repatriation of } \\
\text { select groups }\end{array}$ & $\begin{array}{l}\text { Lockdown in sending } \\
\text { country meant students } \\
\text { could not travel } \\
\text { There were limited } \\
\text { flights and many } \\
\text { countries had } \\
\text { compulsory and often } \\
\text { expensive quarantining }\end{array}$ & \\
\hline
\end{tabular}




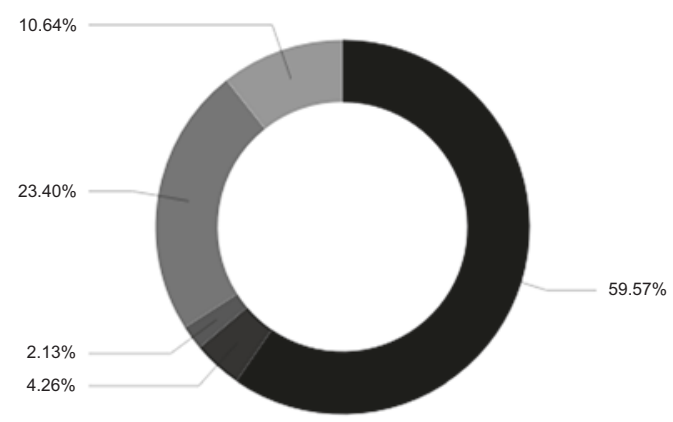

I did not retutn home out of choice.

I wanted or needed to retutn, still intend to return but my travel plans have been delayed due to the pandemic.

I wanted or needed to retutn, still intend to return but my travel plans have been delayed due to reasons that are unrelated to the pandemici.

I wanted or needed to retutn but will stay because pandemic-related reasons have forced me to cancel my plans.

I wanted or needed to retutn but will stay due to reasons that are unrelated to the pandemic.

Fig. 9.2 Decision to stay in UK or leave during lockdown. (Source: Authors' COVID ISM Survey)

stay in the UK or leave and return to their home countries. Over $65 \%$ of respondents indicated that they did not return to their home country, with nearly $35 \%$ indicating that they left the UK and returned to the sending country during the UK lockdown (Fig. 9.2). Our survey asked respondents who decided to stay in the UK for the duration of the lockdown about why they made that decision. Forty per cent of respondents said that they wanted or needed to return home but did not do so. The most common reasons among this subgroup for staying was concern about their migration status.

Overall, the educational infrastructure negatively impacted students' education experience but the specific challenges international students face has received little attention. Survey responses (Fig. 9.3) showed that for the majority of those in taught programmes studies have been slowed with delayed assessment and study breaks as well as due to illness of staff or students. Students often struggled with Internet connectivity as tutoring moved online. Some found that their course options were no longer offered, changing the nature and content of their degree.

At a time of uncertainty, international students did not want to make decisions that would further compromise their precarious situation. This was especially an issue for international students in the UK.

Students engaging in research-related projects were particularly affected as they had to rethink their case studies and methods. Laboratory-based taught courses and research were delayed, sometimes stalled, occasionally abandoned. Some students deferred or stopped their studies as the courses they registered for were not what they were now being offered. Although the fast-moving and changing nature of the pandemic meant that several of these issues were faced by all students, UK students largely went home to their families as they navigated this. This was not an option for international students. 


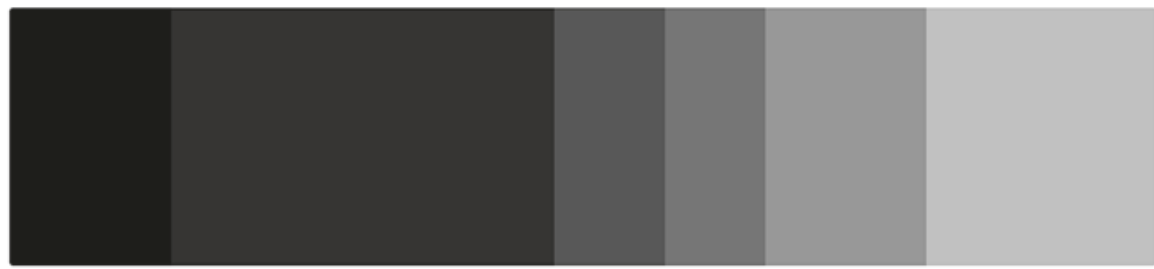

Studies deferred / stopped temporarily $(14 \%)$

Studies slowed (33\%)

Assessment delayed (10\%)

Studies altered e.g. replaced one taught course module with another (9\%)

Assessment altered e.g. examination changed to coursework (14\%) Unable to carry out research $(20 \%)$

Fig. 9.3 Impact of COVID on programme of study. (Source: Authors' COVID ISM Survey)

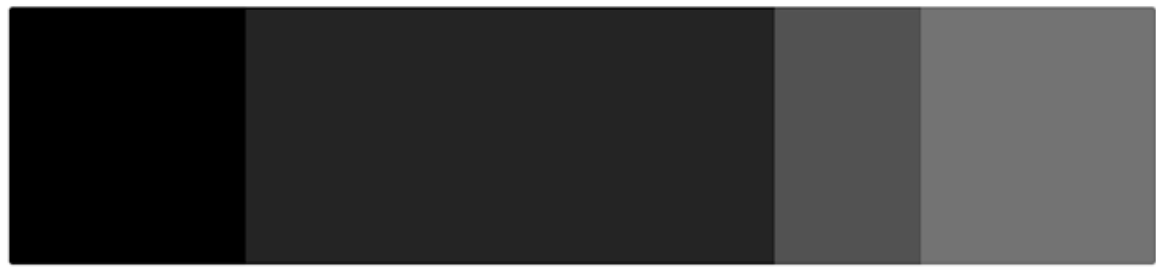

Required an extension of visa (21\%)

Not able to meet face to face study requirements required for the visa category $(46 \%)$

Not been able to meet residency requirements for accessing post-study visas (13\%)

Other (Please use the box below to describe the other ways that migration rules have affected your study) (21\%)

Fig. 9.4 Impact of migration rules on studies. (Source Authors' COVID ISM Survey)

This is because in the UK universities, acting as agents of the UK Border Agency, are required to monitor continuous attendance of classes by international students on Tier 4 Visa category (Jenkins, 2014). The rules also limit the amount of time a student can spend abroad and requires evidence of commitment to uninterrupted study.

There was a lot of uncertainty about the rules as the studies were interrupted and face-to-face study requirements could not be met (Fig. 9.4). As such, students were deeply concerned that they could unwittingly break rules. Any irregularities or missed classes might result in the students losing their migrant status, and potentially, deportation from the country. In fact, nearly $50 \%$ of the respondents identified this as the reason they did not leave as they were uncertain about where they stood with regard to their visa if they did not attend classes. Which rules would be relaxed, how, and when were all unclear. The interlinked nature of physical presence in the country, their studies, and visa was not only stressful but is often little understood as these are often seen as separate issues. Moreover, all these were also linked to their financial position and affected the poorest students the most. In an effort to mitigate 


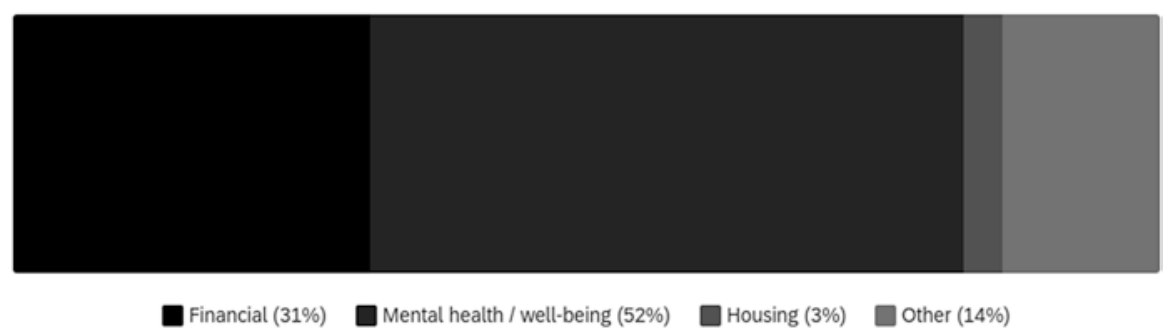

Fig. 9.5 Type of support offered by university. (Source: Authors' COVID ISM Survey)

the uncertainties around migration processes, many students had already paid or expected to pay extra fees related to visa and passport processing due to the pandemic.

This situation was exacerbated by the lack of timely clarifications by the UK government who periodically provided updates on their website as well as through social media and universities but offered little direct advice to the students. While some respondents implicitly pointed to the issue of poor communication, all respondents expressed deep dissatisfaction with the incomplete or incorrect information they received from their universities during this pandemic. Survey respondents indicated that the majority of institutional support and messaging relating to students was on mental health and well-being; only a minority indicated that their institution provided them with any financial or housing support (Fig. 9.5). Thus, structural reasons and infrastructural failures leading to poor mental health were ignored, and mental health was individualised and made into a personal responsibility. The universities were not adjusting the structures and infrastructures of education, housing, and visa to meet student requirements. The lack of institutional support on these issues exacerbated ongoing visa-related challenges.

Moreover, delay in completion of their studies raises distinctive problems for future planning among international students. Post-study plans are an issue for all students, especially in the context of the economic upheaval, job losses, and truncated opportunities that have resulted from the pandemic, but it is particularly so for international students who aim to obtain some labour market experience or embellish their CVs through internships before returning home. Students, especially those from the Global South who had taken loans to study, aimed to recoup some of the money spent on education through working, but were no longer sure if this would be possible. Self-funded students make up the largest share of the international students in the UK. Over $40 \%$ of our survey respondents said they were self-funded and were reliant on funds from friends and family or bank loans. Because of the differential values of currency and the earning power back home, the difficulties of recouping that money by working in their own countries was much greater. The high interest rate charged for loans, often at compound interest, also made the need to quickly pay back the money urgent. Those who had borrowed from family and friends or had been funded by them did not have to pay interest but were usually wealthier as they moved in a network where they knew others who had some money. 
Some respondents expressed concern that if they were unable to complete their studies and were still outside the UK, they may no longer be able to avail of opportunities for further study and post-study visas. Several students spoke about how they had intended to transition into further programmes of study in January or September 2020 but were unable to do so. The importance of post-study work and of being able to retain that ability to have this visa cannot therefore be overestimated.

For many the post-study visa period also offered a bit of slack when they could plan future study and migration. International students have a time-limited period in which their visa is valid in which to accomplish these things. However, international students also varied in how far they had access to resources with which to cushion periods when they have no income. They were incurring expenditure on rent and living as they had no homes to go to while they waited for their plans to materialise, making the utilisation of the post-study visa much riskier. As a result, there was a drop in the proportion of students in the survey who were planning to stay on (Figs. 9.6 and 9.7).

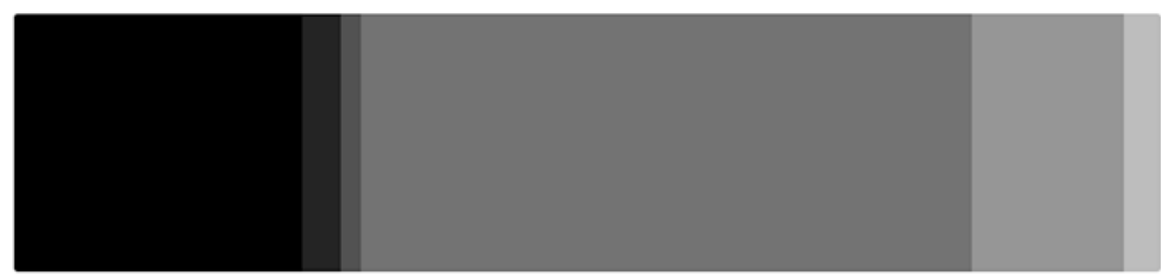

Continue your studies in the country of study (25\%) $\square$ Continue your studies in the home country (3\%)

Continue your studies in a third country (2\%) Wind a job in the country of study (53\%)

Find a job in the home country (13\%) Find a job in a third country (3\%)

Fig. 9.6 Original post-study intentions prior to lockdown. (Source: Authors' COVID ISM Survey)

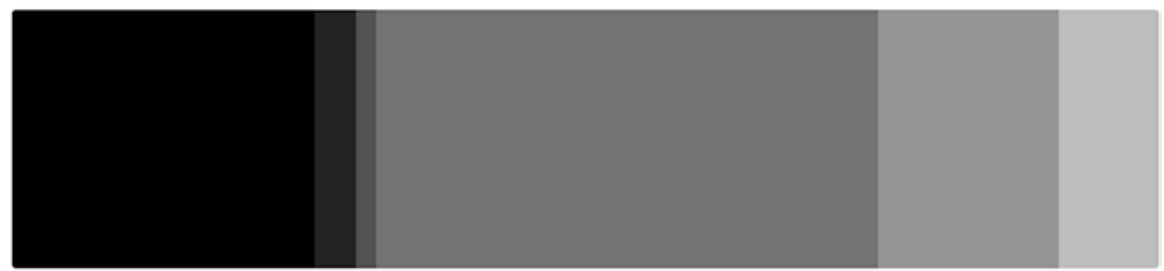

Continue your studies in the country of study (26\%)

Continue your studies in the home country (4\%)

Continue your studies in a third country (2\%) $\square$ Find a job in the country of study (44\%)

Find a job in the home country (16\%) Find a job in a third country (9\%)

Fig. 9.7 Post-study intentions after experiencing lockdown. (Source: Authors' COVID ISM Survey) 
In reflecting back on their intentions, nearly $80 \%$ of the student respondents reported that prior to the lockdown they had intended to stay in the UK, either transitioning to a work permit (53\%) or pursuing further studies $(25 \%)$. However, when asked what they felt after the lockdown, only $70 \%$ intended to make those choices (44\% work and $25 \%$ study). This lack of confidence in post-study stay in the UK was also exacerbated by what students considered as the poor handling of the pandemic in the UK, as it has had some of the highest infection and death rates (thus far) globally. Thus, the drop in those who intend to stay on does not adequately reflect the extent to which migrant students were anxious about this issue. One of the interviewee's reflections on the complexities of how these concerns play out is presented below:

Due to severe sickness, I couldn't submit my dissertation on time, and I didn't get enough time to concentrate well on the dissertation. I had self-isolated myself as I was unwell, and NHS had asked me to stay at home for more than 21 days. Therefore, I requested for visa extension, but I didn't get positive response from the University and the home office. I am literally trapped as I cannot apply for a job anywhere due to COVID 19. I can't even apply for another course as I won't get enough time to search the course because I am getting just one month of time instead of 4 months after completing. (Female, Masters student)

However, it was not only the students who were stuck in the UK who faced challenges. Students who had left the UK when the lockdown was first imposed had been unable to re-enter to pick up their things and wrap up. As one survey respondent reported:

I initially went home for Easter break and stuck here since then. I haven't moved out from my accommodation and is continuing paying. I really hope I can go back soon! To retrieve my things and secure a job! (Female, Bachelors student)

Our project primarily focused on those who were in the UK during the period of the lockdown. Several of our interviewees talked about colleagues and peers who had been stuck in their countries and were unable to leave them. They also spoke about others who left when the lockdown was lifted because they were unable to afford to live due to the high rent costs and were now trying to re-enter the UK. They were struggling to travel.

Those who were looking to start their studies and enter the UK for the first time faced other challenges too. Language testing centres had closed for a period, making it difficult for students to obtain the necessary documentation. The consular services were also operating with reduced staff and at a distance. Moreover, students were unclear about whether the studies would be offered online or face-toface and how studies would progress once they arrived. The different waves of the pandemic were also geographically varied, with source countries going into lockdown at contrasting times than in the UK. The variegated nature of disease spread and intensity, and hence of the control measures, meant that the students faced limitations over their mobility both in their own countries and in the UK. While some students were unable to leave the UK, others were unable to re-enter or enter it due to failures in the entangled infrastructures - migration, education, and finance, namely visa offices, biometric centres, and language testing centres to list a few. 
Moreover, travel itself came to be increasingly brought under new forms of surveillance. Many visa centres were closed, and immigration regulations restricted entry for non-nationals. Covid-19 testing, sometimes difficult to access in the UK but a mandatory requirement for entering some countries, created new costs and immobilities. The mobility of students who had access to sufficient finances to access these was delayed rather than entirely disabled but for others, the costs of mobility were too high. The impact on students has been and continues to be class-differentiated.

The challenges of visa centres, unclear migration policies, ineffective communication, and surveillance by the universities have long been hallmarks of infrastructures of student migration. The slippages and problems of these systems were often apparent to those who had to use these infrastructures, especially those from and in the Global South. They were set up to filter those from some nationalities and classes and they very often did just that, albeit in new ways. Crucially, the effects of the pandemic also furthered inequalities with some students more severely affected, especially those from the Global South. However, the power of intermediaries, infrastructures, and policies in shaping migration outcomes became even more exposed due to the pandemic.

In sum, the infrastructures supporting student mobility in the UK were fractured and incomprehensive. This led to international students being trapped in the UK, unable to leave fearing that they may not be able to return to the UK if they returned home for the period of the lockdown. They were anxious that this would leave them with an incomplete education and with no chance of reimbursement of the money spent. Others left but found it difficult to re-enter. Yet others have delayed their international study plans or dropped them. Thus, infrastructures of mobility led to the selective mobilities and immobilites of students.

\subsection{Concluding Remarks}

This chapter has explored the entangled nature of migration, education, and finance infrastructures that have shaped international students' Covid-19 lives. Drawing on an online survey and select interviews, the paper explored the experiences of migrant students in the UK. It particularly pointed to the issues that students face. For instance, some of the infrastructures around mobility are used to filter students rather than facilitate mobility. They are also situated within a governance complex which is suspicious of mobility from the Global South. The infrastructures of mobility of receiving countries are comprised of various components, the most visible of which are visa policies, visa offices, biometric centres, and language testing centres. The pandemic highlighted how these are entangled with and delivered through educational institutions and mobility infrastructures. The tenuous relations between these infrastructures came unstuck during the pandemic, leading many to become locked within UK borders, while others were unable to enter the UK. Moreover, students were also concerned about their post-study lives and how their future could 
be affected. Crucially, these infrastructures always existed and particularly impeded those from the Global South, but the pandemic exposed not only the politics and operations of these infrastructures but also their failures.

Importantly, these crises are moments which shed light on existing infrastructural arrangements that are often hidden from view. It requires that analysis of Covid-19 goes beyond descriptions and beyond seeing it as an acute unprecedented event. It is all those things but it also much more. It is an analytical invitation to reread the past and see how hegemonic systems have been maintained, who benefited, and how infrastructures were shaped through very particular politics of operations, stitching together these multiple infrastructures. For instance, concerns about attendance can become a problem if there is illness in the family or if financial conditions change. Finances, education, mobilities, and health have to routinely align for international student migration to become successful. However, each of these is also surrounded by infrastructures that routinely fail. Yet these entanglements are rarely recognised either by researchers or institutions providing student-facing services. Rather, institutions routinely see students as cash-cows (Indelicato \& Pražić, 2019). The insistence that it is higher education institutions and national economies that suffered during the pandemic rather than the students themselves suggests a utilitarian and extractive politics to international student migration which infuses their reception, not only now but also in pre-Covid-19 times. These are some of the lessons we learnt from our study.

This poses important questions for researching international student migration in the future. What do the failures of infrastructure that negatively impacted international student experiences of Covid-19 tell us about how infrastructures are routinely experienced? What do crises expose about how infrastructures appear as impediments selectively for some students and at some times? What is the work undertaken to maintain and repair these infrastructures routinely and how complete or incomplete are these operations of maintenance when it comes to intermediaries in the Global South? In short, what are the routine failures that those wanting to pursue international study face on their route to becoming a migrant?

But crises also offer a political opening to think otherwise. They point to analytical opportunities and to moments when change can be identified. This requires that we also explore the emergent, i.e., new arrangements of power and how they will operate to shape international student mobility. For instance, future research on international study must address the effects of negative remittances, situate the class dimensions in international study, and read for how these intersect with gender and race. It should also focus on how students themselves negotiate the entangled infrastructures and their agency in the face of severe constraints. While the UK has retained its international student numbers, this is not globally true. For instance, there has been a significant drop in numbers travelling to some other major destinations such as Australia. Overall student migration numbers have thus dropped. Is this the beginning of a pattern of change or only an aberration? How will individual countries' ways of handling Covid-19 affect who goes where? The impact of the quarantine costs, and potential implementation of vaccine passports are estimated to lower international student flows along certain corridors. Moreover, given that 
international students have underwritten the costs of higher education to the national exchequer and to domestic students, how will nations respond? What role will international distance education (Mittelmeier et al., 2020) play in the unrelenting spread of internationalised higher education? What lessons can this form of internationalisation learn from the experiences of international student migrants? These are all important questions for future research.

\section{References}

Ahlburg, D. A. (2020). Covid-19 and UK Universities. The Political Quarterly, 91(3), 649-654. https://doi.org/10.1111/1467-923X.12867

Bilecen, B. (2020). Commentary: Covid-19 pandemic and higher education: International mobility and students' social protection. International Migration, 58(4), 263-266. https://doi. org/10.1111/imig. 12749

Breines, M. R., Raghuram, P., \& Gunter, A. (2019). Infrastructures of immobility: Enabling international distance education students in Africa to not move. Mobilities, 14(4), 484-499. https:// doi.org/10.1080/17450101.2019.1618565

Briggs, C. L. (1986). Learning how to ask: A sociolinguistic appraisal of the role of the interview in social science research (1st ed.). Cambridge University Press.

Brooks, R., \& Waters, J. (2011). Student mobilities, migration and the internationalization of higher education. Palgrave Macmillan.

Cranston, S. (2017). Expatriate as a 'good' migrant: Thinking through skilled international migrant categories. Population, Space and Place, 23(6), e2058. https://doi.org/10.1002/psp.2058

Dear, L. (2018). British University Border Control: Institutionalization and Resistance to Racialized Capitalism/Neoliberalism. The International Education Journal: Comparative Perspectives, 17(1), 7-23.

Gamlen, A. (2020). Migration and mobility after the 2020 pandemic: The end of an age? (Centre on migration, policy and society working papers WP-20-146). COMPAS.

Hall, S., \& Massey, D. (2010). Interpreting the crisis. Soundings, 44(44), 57-71. https://doi. org/10.3898/136266210791036791

Hannam, K., Sheller, M., \& Urry, J. (2006). Editorial: Mobilities, immobilities and moorings. Mobilities, 1(1), 1-22. https://doi.org/10.1080/17450100500489189

Harvey, W. S., Groutsis, D., \& van den Broek, D. (2018). Intermediaries and destination reputations: Explaining flows of skilled migration. Journal of Ethnic and Migration Studies, 44(4), 644-662. https://doi.org/10.1080/1369183X.2017.1315518

Hu, Y., Xu, C. L., \& Mengwei, T. (2020). Family-mediated migration infrastructure: Chinese international students and parents navigating (im)mobilities during the Covid-19 pandemic. Chinese Sociological Review. https://doi.org/10.1080/21620555.2020.1838271

Indelicato, M. E., \& Pražić, I. (2019). Unpacking 'cash cows' international students and the economism of Asian racialisation. ACRAWSA. Retrieved 7 June 2019 https://acrawsa.org. au/2019/06/03/unpacking-cash-cows-international-students-and-the-economism-of-asianracialisation/

Jayadeva, S. (2020). The impact of Covid-19 on postgraduate-level student migration from India to Germany. Centre for Global Higher Education.

Jenkins, M. (2014). On the effects and implications of UK border agency involvement in higher education. The Geographical Journal, 180(3), 265-270. https://doi.org/10.1111/geoj.12066

Johnson, R., Chambers, D., Raghuram, P., \& Tincknell, E. (2004). The practice of cultural studies. In London. SAGE. 
Kim, A., \& Sondhi, G. (2015). Bridging the literature on education migration. Population Change and Lifecourse Strategic Knowledge Cluster Discussion Paper Series/ Un Réseau Stratégique de Connaissances Changements de Population et Parcours de Vie Document de Travail, 3(1).

King, R., \& Raghuram, P. (2013). International student migration: Mapping the field and new research agendas. Population, Space and Place, 19(2), 127-137. https://doi.org/10.1002/ psp. 1746

King, R., \& Sondhi, G. (2018). International student migration: A comparison of UK and Indian students' motivations for studying abroad. Globalisation, Societies and Education, 16(2), 176-191. https://doi.org/10.1080/14767724.2017.1405244

Mittelmeier, J., Rienties, B., Gunter, A., \& Raghuram, P. (2020). Conceptualizing internationalization at a distance: A 'third category' of university internationalization. Journal of Studies in International Education, 102831532090617. https://doi.org/10.1177/1028315320906176

Nguyen, O. O. T. K., \& Balakrishnan, V. D. (2020). International students in Australia - During and after COVID-19. Higher Education Research \& Development, 39(7), 1372-1376. https:// doi.org/10.1080/07294360.2020.1825346

Raghuram, P. (2013). Theorising the spaces of student migration. Population, Space and Place, 19(2), 138-154. https://doi.org/10.1002/psp.1747

Raghuram, P., Breines, M. R., \& Gunter, A. (2020). Beyond \#FeesMustFall: international students, fees and everyday agency in the era of decolonisation. Geoforum, 109, 95-105. https://doi. org/10.1016/j.geoforum.2020.01.002

Raghuram, P., \& Sondhi, G. (2017). Student migration and development.

Raghuram, P., \& Sondhi, G. (2020). Stuck in the middle of a pandemic: Are international students migrants? OpenDemocracy. Retrieved 21 Julyy 2021, from https://www.opendemocracy.net/ en/pandemic-border/stuck-middle-pandemic-are-international-students-migrants/

Rajan, S. I. (2020). Migrants at a crossroads: Covid-19 and challenges to migration. Migration and Development, 9(3), 323-330. https://doi.org/10.1080/21632324.2020.1826201

Sondhi, G. (2013). Gendering international student mobility: An Indian case study. Doctoral, University of Sussex.

Sondhi, G. (2019). "Settlers" meeting the "Settled": International students encountering the South Asian "Diaspora" in Ontario, Canada. In Outward and Upward Mobilities (pp. 159-176). University of Toronto Press.

Universities UK. (2020). Achieving stability in the higher education sector following Covid-19.

Xiang, B., \& Lindquist, J. (2014). Migration infrastructure. International Migration Review, 48(1 suppl), 122-148. https://doi.org/10.1111/imre.12141

Open Access This chapter is licensed under the terms of the Creative Commons Attribution 4.0 International License (http://creativecommons.org/licenses/by/4.0/), which permits use, sharing, adaptation, distribution and reproduction in any medium or format, as long as you give appropriate credit to the original author(s) and the source, provide a link to the Creative Commons license and indicate if changes were made.

The images or other third party material in this chapter are included in the chapter's Creative Commons license, unless indicated otherwise in a credit line to the material. If material is not included in the chapter's Creative Commons license and your intended use is not permitted by statutory regulation or exceeds the permitted use, you will need to obtain permission directly from the copyright holder.

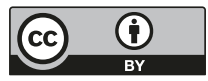

